\title{
A HUMANISTIC PHYLOSOPHICAL ANALYSIS ON WOMEN EXISTENCE IN THE FIQIH OF SYAFII
}

\author{
Iffatin Nur \\ STAIN Tulungagung \\ iffa_nh13@yahoo.com
}

\begin{abstract}
Abstrak
Artikel ini mengkaji kedudukan kaum "nita dalam fiqh Imam Syafi'i. Untuk itu, beberapa karya besar 'mam syafi'i seperti Kitab alUmm, al-Risalah fi Ushul al-Fiqh, Qaul Ladim dan Qaul Jadid ditelaah secara mendalam dengan menggunaka pe dekatan filsafat Humanis. Semangat pemberdayaan kaum pe muan yang menampakan nilainilai kemanusiaan dalam karya al-S, ? dapat ditemukan baik dalam aspek metodologi (ushul Fiqh) $m$. un ada produk hukum (Fiqh) yang dihasilkan oleh beliau. Dalam netodologi, pengembangan prinsipprinsip Maslahah Mursalah y .r. $m_{t}$ lgacu pada kepentingan masyarakat luas merupakan suatu ind a bohwa nilai-nilai kemanusiaan menjadi bahan pertimbangan uta a dal m mengeluarkan suatu produk hukum.
\end{abstract}

Abstract

This article examines the position of women in the fiqh of Imam Shafi'i. To that end, some of the major works of Imam Shafi'i such as : Kitab alUmm, al-Risalah fi Usul al-Fiqh, Qaul Qadim and Qaul Jadid are explored in depth by using humanist philosophical approach. The spirit of women empowerment which reveals human values in the work of al-Shafi'i can be found both in the aspect of methodology (usul fiqh) as well as in the product of law (Fiqh) generated by him. In the aspect of methodology, the development of the Maslahah mursalah principles refers to the public interest, indicating that the values of humanity become a primary consideration in issuing a legal product.

Keyword: Fiqh, Humanistic, Women, Shafii 


\section{A. Background}

In the actual-modern discourse in the Muslim world, the ethical, humanistic and legal aspects, have become a central concern in the social sphere. Accentuation on these aspects can be detected from the vast attention given by Islamic jurists towards any efforts to women humanization, both as an individual figure or in conjunction with their position in a family, as a common reaction against Western cultural outlook. ${ }^{1}$ Essentially, the modernists offer new Islamic humanism through social reform program in order to fight for women' dignity, freedom and humanization process.

In 1994, some Muslim leaders collabor ${ }^{+a}$ d with the Catholic churches criticized the agenda of "Confer ace $n$ Population and Development' in Cairo, which was presumed of bu ng held to support sexual freedom and to justify the neces $c c$ abortion as a birth control and sex education to people wh in wuld be applied in their country. The outputs of the confereno v. re considered to have a potential to threaten the stability a id secial values of both Muslim and traditional Catholic families $\mathrm{s}$ ov $\mathrm{d}$ the Western method on family planning as mentioned the applied in their country.

The equality of level and ntus of women became a main stream to the modernists. $\checkmark$ argued that Islam gives equal freedom and rights to wo sen in particular they fought for the rights of women in edu $4 \mathrm{~L} \sim \mathrm{r}$ and employment. In Egypt, Qasim Amin (1865-1908) publis ad a book about the "emancipation of women", to give suggestions tha 4 should have basic education if they are aimed to play a 20 ' 1 society. In his book, Al-Mar'ah al-Jadidah, which was publishea vo years later (1901), he called back the grand concept of the twenticth century, namely: freedom, progress, and civilization. $^{2}$ In Iran, Mohammad Khatami, while being a Minister in the 1980s, gave hope to women that under his future presidential time, they may compete to achieve equal status along with men. He said that women were very competent to play the roles that were

${ }^{1}$ Fazlur Rahman, Islam, Second Edition, (Chicago: University of Chicago Press, 1988), p. 232

${ }^{2}$ Dessouki, "Islamic Modernism," in Mircea Eliade, ed., The Encyclopedia of Religion, p. 16. 
not only limited to their existence and the country should provide administrative opportunities even at the highest levels. ${ }^{3}$

As in Iran, the focus on the humanization of women was also given high attention related to human rights regarding political, religious, and social change aspects in other places. Some Islamic countries that paid high attention to that issue were Pakistan, ${ }^{4}$ Uzbekistan, ${ }^{5}$ and Afghanistan. ${ }^{6}$

The reality in those modern Islamic worlds indicated a core issue that the Islamic law is facing a developing and changing conditions and values. The Islamic modernist were keen to fight for a condition that the diversity in the modern era can express itself in the form of interpretation activities and elig ous experiences which are more organic to the area of culty al similation where their value system may give fresh meanin ${ }^{t}, h$ man life.

The preface just mentioned giv suris to a question as to whether the modernists' ideas are com ' $e_{k}{ }^{1}$ new and had not been reviewed by the Islamic law or by clas cal Isamic jurists. The answer is of course not; since both in the Q $\mathrm{t}$ ran and al-Sunnah and in the formative period of Islamic law sv icsues on emancipatory values and humanization of women had seen elaborated, one of which was the conception of the Sha li . n adzhab (school of thought).

Assessing the human "vo Tyem in Islamiclaw conceptually or empirically can be ob thed through a dialogue presentation between Wahbah Zuhaili and syafiq Hasyim's views. Zuhaili stated that inside women on $r$ ind entertainment and charm and a

3 Anonymous, "s esidential Elections, Political Parties; Islam; Voter Behaviors; Social Change» in slam and Ballot Box, (Economist Journal, Vol. 343, May 31, 1997), p. 42. Khatami also made easier for censorship, allowing some foreign publications and filmmaking. All of them were in the composition of his campaign for human rights, personal freedoms, and the rule of law. See also Barbara Smith, "Islam, Human Rights; Law Enforcement; Social Conditions and Trends" in Bully Boys at Work, (Economist Journal, vol. 342, June 18, 1997), p. 8-10.

${ }^{4}$ George Melloan, «Foreign Policy; Human Rights; Religion» Who's in Charge of Human Right These Days? (Wall Street Journal, May 12, 1998), p. 21-23.

${ }^{5}$ Anonymous, «Presidents; Political Behavior» in the Getting There (Economist Journal, vol. 340, 21 September 1996), p. 41.

${ }^{6}$ Hugh Pope, «Civil War: Islam; Economic Conditions» in Reality Check: Afghan Taliban, For Better or Worse, Seems There to Stay, (Wall Street Journal, 3 September 1998), p. 2. 
capacity to lighten the burdens of life and to support their men. So it is not logical if this condition is abandoned, the function is turned off, or their liberty is restricted without the right direction. It is verily not true to drown their rights, to disparage their honors or to leave them in the tradition and social shackles. Islam has raised the emancipation and gives due respect to women both in muamalah (inter-human relation in the form of daily life activities) and ibadah (worship). There are no restrictions for both women and men to compete in doing good deeds in order to achieve a higher degree on the side of Allah SWT. ${ }^{7}$

The Zuhaili's views suggest that women in the conception of Islamic law have equal opportunities $y$ th hen in scholastic achievement in life. In fact, Islam has raise $1 \mathrm{t}$ dignity of women, compared to their social historical backs $n$ before Islam came. Therefore, Islam through its shari'ah ( $t$ ach gs) advocates women humanity. By this, it is then not lega $v$, tified if their condition is neglected, the function is turned orf, their freedom is restricted, their rights are drowned, and their figr ity as human is humiliated.

On the other hand, Syaf Hasyim, in his editorial writing about the "value" of women, state that in the case of reproductive rights of women in Islam, t $\mathrm{t}$ e $\mathrm{in}^{\mathrm{r}}$ that is developing around us regardless of its authenticit an ${ }^{7}$-ralidity - has become an inhibiting factor just like culture, $\mathrm{p}$, tics, and economic. Women are valued half the price of men, ot ty physically but also of their rights. Contrarily, their dut is b gger than men. ${ }^{8}$ So, on this fact, the historical aspects of 1 an c law are tested.

These con ual and empirical-critical dialog needs to be analyzed philosopt ${ }^{\text {cally. }}{ }^{9}$ This is so because, in general, in the

${ }^{7}$ Wahbah Zuhaili, The Quran: Paradigm of Law and Civilization, translated into Indonesian by M. Luqman Hakiem and M. Fuad Hariri, titled : Al-Qur'an : Paradigma Hukum dan Peradaban (Surabaya: Risalah Gusti, 1996), p. 180.

${ }^{8}$ Syafiq Hasyim, ed., Menakar "Harga" Perempuan : Eksplorasi Lanjut atas Hakhak Perempuan dalam Islam (Measuring the "Price" of Woman: Advanced Exploration on the Rights of Women in Islam), (Bandung: Mizan, 1996), p. 6.

${ }^{9}$ Mustafa Abdul Raziq explained that the philosophy of Islamic law is not the same as the wisdom of Islamic law. Nevertheless, as the enrichment insight to the analysis, there are some scholars who believe that the philosophy of Islamic law is the wisdom of Islamic law. Refer further to Fathurrahman Djamil, Filsafat Hukum Islam (Philosophy of Islamic Law), (Jakarta: Logos, 1997), p.12-15. 
view of Islamic law's philosophy, human welfare is always put forward. ${ }^{10}$ This putting forward has formed a common ideality in the principles of Islamic law. Then, even if there is a gap between the ideals of Islamic law with empirical reality, the first question that needs to be studied thoroughly is the welfare aspects of the philosophy that produces the Islamic jurisprudence although it also requires further observation in its relation with social change issues. $^{11}$

The second question is: How are the circumstances of socio-cultural and political at the time of the related figh (Islamic jurisprudence) being produced? This problem appears related to the fiqh's productivity and application in hum n li e that can not be separated from the socio-cultural condition The problem requires solving through historical study.

The third question is: Does the fir mad scate towards female humanity? This problem appears rela a the evaluation of the gap between the ideal-juridical con epts of Islamic law with the empirical reality of social life.

Arising from the elabor and relating to the three questions above, this paper attem is to capture comprehensively the values of women humani $y{ }^{n}$ he Shafii madzhab conception through his several monur in works, especially his magnum opus : al-Risalah and al-Umr . This paper tries to uncover humanistic values in Shafii's fiqh 'voce cy towards women philosophically and historically.

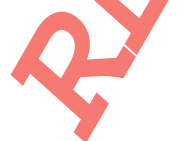

${ }^{10}$ Djamil explained that the philosophy of Islamic law is the knowledge of nature, secret, and objectives of Islamic law, both concerning the material of the law as well as its adoption process. While the purpose of shari'ah as the law of Allah the God Almighty on this world is to restore the benefit, peace and happiness of mankind. Refer further to Fathurrahman Djamil, p. 14

${ }^{11}$ Muhammad Khalid Masud, Islamic Philosophy of Law and Social Change, translated into Indonesian by Yudian W. Asmin, titled Filsafat Hukum Islam dan Perubahan Sosial (Surabaya: Al-Ikhlas, 1995). This book raised the concept of maslahah of Abu Ishaq al-Shatibi (d. $780 \mathrm{H} / 1388$ A.D.). The concept was developed as a fundamental characteristic of the theory of Islamic law which is adaptive to social change. In his al-Muwafaqat, al- Shatibi presented his doctrine, al-Maqasid al-Shari'ah containing exposition of various aspects of the concept of maslahah. 


\section{B. Discussion}

To be able to do an objective and valid scientific study on the mindset of a prominent figure, then it is necessary to elaborate in advance the setting of political, social, cultural, economic, educational and religiousness condition where and when he or she was born, educated, initiated his or her ideas until the time of his or her death. This is important as the academics agreed unanimously that the socio-cultural conditions affect a person's patterns of thought and ideas. Here's a global snapshot biography of the founder of the Shafii school of thought.

\section{Imam Shafii in history track}

His full name is Muhammad ibr Id ibn al-Abbas ibn Uthman ibn Shafii ibn al-Sabi 'ibn Yazi i n Abd al-Muttalib ibn Hashim ibn 'Abd Manaf ibn Qasi ibn slab later then known as Imam Shafii (150-208 / 767-820). ${ }^{12}$ So 76 othors disagreed about the place of birth, whether in Gaz , a sniall town in Palestine; in Ashkelon, a larger town not far fro $n C$, za, or in Yemen. But most authors mentioned his birthpl was in Gaza. ${ }^{13}$ http://translate. googleusercontent.com/translate___edn14 His genealogy meets with the Prophet Muhamma ic "bd al-Manaf. ${ }^{14}$

Imam Shafii's lifet' ᄁu ras relatively not long. He lived for 53 years according tr e calculations of the solar year or 54 years according to Islan c ca endar. Even so, his short life was very contrast to his abund $N$ rks, indicating how productive he was when produced pap

At the age - IIIf Imam Shafii had memorized the Quran. At the age of ten year old, his father died and then he was taken along by his mother from Palestine to Mecca. In Mecca he learned to the experts of fiqh and Hadith. His first famous teacher in Mecca

${ }^{12}$ Majid Khadduri, «Al-Shafii» in Mircea Eliade, ed., The Encyclopedia of Religion, vol. 13 (New York: Macmillan Publishing Company, 1993), Al-Imam al-Shafi, (Beirut-Lebanon: Dar al-Kutub al-'Ilmiyah, 1992), p.5, Here, it was written that Shafii's life was in 150-204 H / 767-816 AD. His birth year coincided with the death of Imam Abu Hanifa.

${ }^{13}$ Khadduri, «Al-Shafii .... p.195; Mūti, Al-Imam Al-Shafii .... p.5-6.

${ }^{14}$ Jalal al-Din Abd al-Rahman ibn Abi Bakr al-Suyuti, Uqud al-Zabarjad 'ala Musnad al-Imam Ahmad, (Beirut: Dar al-Kutub al-Ilmiyah, 1987), p.6. 
was Muslim bin Khalid, a Sufi which granted him a warranty to preach. ${ }^{15}$ Later he studied in Medina under the guidance of al-Imam Malik ibn Anas, the chief judge of the Hejaz and the founder of the Maliki school. He was known as a follower of Imam Malik until his migration to Iraq. In Iraq, he learned the doctrines of the Hanafi school through al-Shaybani's books and through his contact with the followers of the Hanafi school. From these interactions, his scientific insight became broader so that he was able to analyze the strengths and weaknesses of both Maliki and Hanafi schools and tried to combine both.

In the year $804 \mathrm{AD}$, at the age of 37 vears, Imam Shafii left Iraq. ${ }^{16}$ His scientific investigation onto $\mathrm{r}$ any Islamic scholars from different schools of thought at varis aces and various subjects of study made him rich in scienti st sures and cultural experiences. Nevertheless, he insisted to $\Delta m_{t}$ ine what he learned keenly from both madzhabs with his ow aracter, as evidenced by the birth and rapid development of as own madzhab in the area of Islamic jurisprudence (fiqh). The nde endence of his school of fiqh was not determined domina na even it can be said that was not affected, by the orientat $n$ of his teachers' thoughts or any other academic resources $\mathrm{H}$ in deed even made a critical study of them.

Such independen sas expressed in his innovation to the strategic tools need by the field of jurisprudence, such as his pioneer work of I 1 legal methodology (ushul fiqh) that can be found in his on mental book, al-Risalah. Shafii was also known as a defenc. or hadith. ${ }^{17}$ Ahmad bin Hanbal, the owner

${ }^{15}$ Mùti, Al-Imam al-Shafii ..... p. 5, al-Suyudi, Uqud al-Zabarjad..... p. 6.

${ }^{16} \ldots$ _ p. 195-196, The authors disagreed regarding this case; most of them suggested that he went to Syria and the Hejaz and then went back to Iraq in the year 810 A.D.; others did not mention his visit to the Hejaz and reported that he lived in Iraq in the year 814 A.D. and went to Egypt after a stop in Syria for a while. In Egypt, al-Imam al-Shafii firmed his position and built his madzhab (school of thought). His activity went on until one day when he was attacked by some followers of the Maliki school so that he was seriously wounded and died a few days later.

17 Al-Jundi, al-Imam al-Shafii Nasir al-Sunnah wa Wadi 'al-Uhsul, (Cairo-Egypt: Dar al-Kaib al-' Arabi, 1966); Moenawar Chalil, Biografi Empat Serangkai Imam Mazhab (A Biography of Four Imams of the School of Thought), (Jakarta : Bulan Bintang, 1955), p. 207. 
of the honorable title as The Leader of Hadith Experts (regarding to traditional / orthodox schools of the Ahl al-Sunnah wa al-Jama'ah), ${ }^{18}$ acknowledged that: Should there be no Shafii, surely we would had not known the fiqh of hadith. ${ }^{19}$

Shafii's Islamic law system can be explored through his work, al-Umm (The Mother), ${ }^{20}$ while his work of law principles can be clearly read from his book: al-Risalah fi ushul al-Fiqh. In these two magnum opuses, his law doctrines and methodology are found. His work of ushul fiqh has been the most systematic and coherent book, which discusses the significance and relativity of every source of law, and how the rules of law are absorbed from them. ${ }^{21}$ Shafii also wrote several other books, like Kitab 'Ahkam ura , and al-Musnad, a hadith compilation.

Two major works of Shafii, namel $q y \mathrm{~m}$ and al-Risalah was compiled by al-Rabi 'ibn Sulayman al-M t ad in addition, there are other works that he wrote; Jami'ul ' $\mathrm{lm}$, ${ }^{2} \mathrm{IL}_{\mathrm{L}}{ }^{+} \mathrm{r}$ al-Istihsan, ${ }^{23} \mathrm{Al}$-Radd 'ala

${ }^{18} \mathrm{~W}$. Montgomery Watt, Islamic "Msophy and Theology: An Estended Survey, (Edinburgh: Edinburgh University Ass, 1985), p.58; Cyril Glasse. The Concise Encyclopedia of Islam, (San Francis adper Collins Publishers, 1991), p.170-171, and GE von Gruneboum, Classico 1.Jam 1 History 600 A..D-1258.A.D., (Chicago: Aldine Publishing, 1970), p.90-92; HAP G h, et.al. The Encyclopaedia of Islam, Vol. 1, (Leiden: EJ Brill; London: Luzac \& Co.. 960), 272.

19 Al-Jundi, Al-Qur is a -Manhaj al-'Tlmi al-ma'asir, (Cairo-Egypt's Dar alMa'arif, 1984), p.255.

20 This oc $1 \mathrm{r}$ as the transcripts of his lectures written by his prominent followers, es $s_{P}$ cially al-Rabi ibn Sulayman al-Muradi (d. 880 A.D.), alBuwayti (d. 845 A.D.), and al-Iuzani, (d. 877 A.D.), and was corrected by al-Shafii when the transcripts were delivered to him. All of his followers in Egypt were responsible to the books that had come down to them, whether the transcripts were copied or dictated from the original writings.

${ }^{21}$ Khadduri, «Al-Shafii”, p.196: see also Ahmed Hasan, The Early Development of Islamic Jurisprudence, (Delhi: Adam Publishers and Distributors, 1994), p. v, xv.

${ }^{22}$ This book contains Shafii defense to the sunnah of the Prophet Muhammad.

${ }^{23}$ The book contains Shafii's critics to the Islamic scholars in Baghdad (Iraq) that employed the method of istihsan, particularly Hanafi. He stated "“man istahsana fa qad syara'a, kama anna man istashlaha fa qad syara'a aidhan, (whoever carries out an istihsan then he is just like making laws, and so is any person who carries out an istishlah then he is making a law too). 
Muhammad ibn Hasan, ${ }^{24}$ Siyar al-Ausha'i, ${ }^{25}$ Al-Fiqh, all of which were compiled by al-Imam al-Haramayn bin Yahya; Al-Mukhtasar al-Kabir, al-Mukhtasar al-Saghir, al-Faraid, al-Jami 'al-Kabir and al-Jami' al-Saghir, which were compiled by al-Buwayti and al-Muzani. Al-Hujjah, was compiled by al-Za'farani and Al-Sayr, was compiled by Abi 'Abd alRahman Ahmad bin Yahya. ${ }^{26}$

The involvement of Shafii's students was highly significant in preparing some of his works. They contributed to his works based on the results of their study to Imam Shafii with the method of imla' (dictation). His book titled Ikhtilaf al-Hadith (the Disagreement of Hadith), was the only book compiled by Shafii himself. ${ }^{27}$

In his fiqh's conception, there are term kn wn as qaul qadim (old sayings) ${ }^{28}$ and qaul jadid (new opinions 129 se two terms are closely related to historicity factor in his $n$ pecially from that of Baghdad to Egypt. This factor was in $1 \mathrm{~m}$ of academic and socio-cultural facts that he responded $\mathrm{hu}^{\mathrm{t}}$ hese two forms of qaul (opinions). It was academic aspects nat became the background for him to change opinions from qau qar $m$ to qaul jadid. From this latter qaul (opinions) Shafii's sc ${ }^{-1}$ f thought began to spread and grow.

The socio-cultural asp $\mathrm{ct}+{ }^{+t}$ at caused him changing some opinions were new things it $\mathrm{Es}_{\text {. }} t \mathrm{t}$ that were different from those he found in Baghdad (Ira 4), such as people's customs, norms of

${ }^{24}$ This book revie , 'ha i's arguments, rebuttal, and defense against the accusations and attacks do 5 , al-Imam Muhammad ibn Hasan the second, a Medina scholar who was fo lov er of the Maliky school

${ }^{25}$ This book conta 's Shafii's defense towards al-Imam al-Aushāi $(88-150 \mathrm{H})$ who was an expert on haditl and was regarded as a prominent hadith scholars in the period before Shafii was born.

${ }^{26}$ Al-Mūti, al-Imam al-Shafi, p.47.

${ }^{27}$ Chalil, Biografi ...., p.243. In addition to this book, other Shafii's works with no compiler's identity were not given any information about their compilation, whether they were done by Shafii himself or by others.

${ }^{28}$ Qaul qadim relied on his work of al-Hujjah, produced in Baghdad, which was closer to the stream's character of ahl hadith (traditionalist faction) and bore a main purpose as a resistance to the stream of ahl ra'y (rationalist faction).

${ }^{29}$ Later, when he was in Egypt, some of the students of al-Imam Malik visited him. When he proclaimed his Qaul Jadid through some works intended as a rejection of the school of al-Imam Malik, they denied his views and harmed him. For more information, see: Mu'ti, al-Imam al-Shafi, p.46-47. 
social life and social needs. This difference obliged Shafii to adapt legal provisions that could be applied in a new place. ${ }^{30}$

Regarding to the dimensions of space, it can be stated that qaul qadim was born in the period of Iraq while qaul jadid was born in the period of Egypt. During the period of Iraq, there were two major works written by Shafii, namely: al-Risalah and al-Hujjah. While other works, including al-Umm, was written in Egypt.

\section{Humanistic Phylosophical Analysis On Women Existence In Shafii's Fiqh Conception}

Humanistic values in Shafii's fiqh seem to get serious attention especially in his investigations ${ }^{31}$ tr pr blems of women. What he did was well recorded in his wo w nental work: "alUmm" (The Mother), ${ }^{32}$ and periodicals of $0, \mathbb{U}^{2}$ im and Qaul Jadid. ${ }^{33}$ This article attempts to reveal - philos oh dly and historically humanistic values in Shafii's fiqh adv c cy towards women which became a landmark in the humanis val des of Islamic law.

To be able to conduct a s ienf fic study of the material of Shafii's fiqh, a necessary correntual insight of jurisprudence taxonomy which is widely accep 4 by scientists or jurisprudence experts is needed. In the mor es o scourse as explained by Khallaf

${ }^{30}$ Chalil, Biograj, p.246; Fathurrahman Djamil, Filsafat Hukum Islam (The Philosophy of Islamic Law), Pa1. One (Jakarta: Logos, 1997), p. 116.

${ }^{31}$ Majid Khadduri, "Al-Shafi" in Mircea Eliade, ed., The Encyclopedia of Religion, vol. 13 (New York: Macmillan Publishing Company, 1993), p.195-196. Al-Shafii in the study and production of Islamic law in Mecca, Medina and Baghdad. Then he proceeded his investigation on fiqh to Syria, Hejaz and Egypt. See also Auddin Nata, Metodologi Studi Islam (Methodology of Islamic Studies), (Jakarta : Raja Grafindo Persada, 1998), p.255.

32 , p.196, 198. It was described by Khadduri that the book of al-Umm consists of 7 volumes, edited by Ibn Jama'ah, (Cairo, 1904-1908). But, the editions by Shakir (Beirut-Lebanon: Dar al-Fikr, 1990) that the researcher found showed that alUmm consists of 8 chapters and were packed into 5 volumes.

${ }^{33}$ Among the works that discuss both Qauls of Imam al-Shafii is Nahrawi Ahmad 'Abd al-Salam's paper, al-Imam al-Shafii fi madhabih al-qadim wa al-Jadid (1988). 
and Zuhaili, ${ }^{34}$ the jurisprudence taxonomy is divided into seven areas, ${ }^{35}$ namely:

1. Al-Ahkam al-ahwal al-shakhsiyah (civil law) ${ }^{36}$

2. 2. Al-Ahkam al-Madaniyah (law between individuals / citizens) $)^{37}$

3. Al-Ahkam al-jina'iyah (criminal law) ${ }^{38}$

4. Al-Ahkam al-murafa'at (Law of Procedure) ${ }^{39}$

5. Al-Ahkam al-dusturiyah (law of regulations) ${ }^{40}$

6. Al-Ahkam al-dauliyah (state law) ${ }^{41}$

7. Al-Ahkam al-iqtisadiyah wa al-maliyah (law of properties) ${ }^{42}$

$3 \overline{4}$ Abd al-Wahhab Khallaf Ilm Ushul al-Fiqh, (Ku an Dar al-Qalam, 1977), p.32-33: Wahbah al Zulaili, Ushul al-Fiqh al-Islami, (Damsh.. Dar al-Fikr , 1986), p.438439.

${ }^{35}$ In the perspective of ushul fiqh, these $v$ egions are included in the region of interaction among fellow human vin whether as individuals or as members of society. This is the third law o, tained in the Quran. For more information, see Khallaf, 'Tlm Ushul al-Fiqh, p 32 ar al-Zuhaili, Ushul al-Fiqh ...., p.438.

${ }^{36}$ With regard to the kinship that go erp relationships between husband and wife, between relatives, and inherita there are 70 verses in the Quran)

37 With regard to the activitie sewween individuals, which includes trade, pledge, mortgage, company, wh a air to regulate the relationship between individual's honor and to protect an.

${ }^{38}$ With regard to the crim and $N$ sanctions, which aims to protect human life, their properties and rights an to limit relationships between the criminals and the law upholders as well the s ciety (there are 30 verses)

${ }^{39}$ With regard to $t e$ in icial process, sentences, testimony, and oath, which aims to regulate the pra $+i$ es in order to conceive justice and also aims to ensure the continuity of 1 in an ife (there are 13 verses)

${ }^{40}$ With regard to gal procedures and law resources, which aims to limit the relationship between the government and a statement of individual and public rights (there are 10 verses)

${ }^{41}$ The regulations of the relationship between the state and its citizens as well as with other countries; regarding to (a) Islamic government relationships with other countries i.e. the general state laws (qanun), (b) matters regarding to nonMuslims living within an Islamic system of government i.e. the specific state laws, aimed at limiting the Islamic government relations with other countries both in a peace and a war conditions and to limit the relations between Islamic community with other communities in Islamic countries. Also included in it are the regulations about asylum and political extraditions (there are 25 verses)

${ }^{42}$ With regard to the rights of the individual properties and accountability in managing the properties as well as the states' rights and obligations, intended to regulate relations dealing with properties between rich and poor people and 
Furthermore the humanistic values in Shafii's fiqh are highlighted in two aspects, namely the methodological aspects and the material / production aspects.

Firstly, in the aspect of methodology (ushul fiqh), the use of qiyas (analogy) in Shafii's fiqh represents a landmark of the value of humanistic presence in developing principles in legal sources to cover issues that are not found directly in the Quran 'an and Hadith.

The humanistic values are characteristically common in the framework of ijtihad on jurisprudence due to the involvement of aspect of $i j t i h a d i a h$ thoughts on it. Therefore, thev do no longer belong to Shafii himself but also to every mujtahid $\mathrm{M}$ slim of adequate capability to carry out ijtihad i.e. to study ar $1 \mathrm{p}$ - ent his or her own legal opinions regarding to Islamic laws sprudence based on the Quran, Hadith and other acceptabl sla dic law sources).

With the trend of qiyas, he ref. se' he model of "speculative reasoning" which was practiced by thl ray, ihtihsan, and al-masalih al-mursalah, istishab as the basis and me hod of istinbat of the law. ${ }^{43}$ Shafii was extra careful against involvement of sources outside the two principal ones of Islamic aw (i.e. the Quran and Hadith). Even, according to Chalil, hey as "n own as the "defender of hadith", ${ }_{4}$ which is in tune with the a ses of al-Jundi and Hambali.

The humanistic $x$ tence of women in the Shafii's fiqh conception can be elab atec as follows:

\section{Humanistic Phyıo or nical Analysis On Women Existence In the Law of $r$ o $e^{\prime}$ ties}

The first thing to elaborate is the rights and freedoms for women to do business transaction. Throughout Shafii's explanation about the law on trade activities, it was found that the rights and freedom of trade ('ahliyah al-tasarruf) between women and men are

between the state and individuals (there are 10 verses).

${ }^{43}$ Ann Elizabeth Mayer, "Islamic Law: Shari'ah", in Mirca Eliade, ed., The Encyclopedia of Religion, vol. 7, (New York: Macmilan Publishing Company, 1993), p.434-435. See also Zuhaili, al-Fiqh al-Islam wa Adillatuh, chapter 1, (Damshiq: Dar alFikr, 1996), p.36.

${ }^{44}$ Moenawar Chalil, Biografi Empat Serangkai Imam Mazhab (A Biography of Four Imams of the School of Thought), (Jakarta : Bulan Bintang, 1955), p.207. 
equal, both considering terms, khiyar, or contract of sale. ${ }^{45}$ Shafii requires that in economic activities women must not be treated differently from men. Despite the fact that women are bound by ethical factors in their social status, this should not prevent them to obtain the same opportunities as men in the economic field.

The second thing to elaborate is business and economic opportunities for women in the context of the absence of obligation in performing Friday prayers. In his jurisprudence, Shafii does not oblige women and children to carry out the Friday prayers. By this, it is understood that Shafii insisted on the obligation for men to perform Friday prayers along with the assertion in the context of trade activities.

In fact, he even states that any trade ti - es are prohibited when the call (azan) to Friday prayer eche $s$ khatib (the Friday prayer preacher) is already in the pul $\mathrm{H}$. other people who are not obliged to do Friday prayer, ti sy n carry out the trade activities because the ban for doing s r aims to meet the obligations of Friday prayers.

From this Shafii's explan in it can be interpreted that he tried to reinforce his fiqh in pro ding opportunities for women to trade when men perform $r$ is aw prayers. This assertion is more obvious when the main ref "en 7 , i.e. the Quran, ${ }^{46}$ only describes the order for leaving trad ctivities is only at the time whenever the call to Friday prayer i ech (ed while the Hadith of the Prophet ${ }^{47}$ describes that there is 7 andatory to women and children to perform Friday praye

45 Al-Shafii, al-Umm, chapter 3; resumed in chapter 4, p.3-62. Equal opportunity for both women and men in the economic activities is different from their freedom in marriage. Women and men in ahliyah al-nikah have a different freedom, although the humanistic values can still be found in it.

${ }^{46}$ The Holy Quran, Surah 62 (al-Jumu'ah), verse: 9. Here Allah says: "Ya ayyuha alladhina amanu idha nudiya li al-shalat min yawmil Jumu'ati fas'aw ila dhikrillahi wa dharu al-bay', dhalikum khairun lakum in kuntum ta'lamun"

${ }^{47}$ Shafii, al-Umm, chapter 1, p.218. The Prophet said: “tajib al-jum'ah 'alakuli muslimin illa imra'ah aw sabiya aw mamluk" (The Friday prayer is obliged to any Muslim except women, kids and slaves) This hadith was narrated by Shafii from Ibrahim ibn Muhammad from Salmah ibn' Abd Allah al-Khatami from Muhammad bin Ka ‘b alQurzi from a man of Bani Wa'il. 
If it is connected to the cultural setting of Baghdad and Egypt communities that had been cosmopolitan as well as a high level of women humanity there, it can be determined that at that very time women had played a significant role in the market economy. In these circumstances women have business opportunities for a longer time span than men since the latter have to allocate some of their time to perform Friday prayer obligations.

The third thing to elaborate is women's ownership rights in properties. Women have every right to manage, organize and spend their own property. Here there are two key terms, namely the rights and ownership..$^{48}$ Any property that becomes a right of women, in turn, would be theirs if such property had een given to them by the obliged party. For example, when a $y$ mo is still under the responsibility of her parents, the neces it $s$ of life (e.g. income, wealth) becomes the obligation of her $\mathrm{r}$ a en , as long as she is still immature and do not have her own in on so when she gets married, her parents' obligation moves to he riusband.

Nevertheless, Shafii provide gre at opportunities to women to seek their own field of econor so long this does not cause any calumny that may threaten the I rmony of their family life. Any wealth resulted from such of of $h$ comes a wholly-owned property of women and is separated "or. the family's properties that are the responsibility of the hus a d such wealth is also separated from the property of gono-gir a Ja anese term which means any wealth that a family gathers it $\mathrm{g}$ a marriage period resulted from the husband's business tiv, es) in the family inheritance.

In this con $\mathrm{v}$, women can use the income obtained from their work, dowry and maintenance from her husband according to their own interests and needs, including her will to help the needs of her relatives.

${ }^{48}$ For the term 'rights', there are more or less some level terms, e.g. beselit (a Javanese term, means a certificate or a legal document of possession or right) or some sort of decrees for government officials regarding their wages. While 'possession' is realized if the right had been received actually from the parties obliged to give the rights. 


\section{Humanistic Phylosophical Analysis On Women Existence In State Laws}

The state laws that are discussed in Shafii's fiqh begins with tax issues, and then develops onto the issue of jihad, the status of the war zones, migration, religious status of citizens and their social interactions (including inter-religious marriages), religion conversion, economic, prisoners and slaves , the political identity of citizens, and crime.

His advocacy towards women, in line with the focus of issues, covering economic issues in its close relation with religion conversion and social relations in a political $\mathrm{se}^{+} \mathrm{m}$, is elaborated as below:

The first thing Shafii raised into co cern was the economic security for non-Muslim women who convert $1+5$ Islam / dhimmiyah, as well as Christian, Jewish and ahl al-Ki h (pcople of Book) women who converted to Islam while they were pregnant, they had a right for a guaranteed income unti the gave birth. If they were breastfeeding, they were entitled to $u$ stfeeding wages. However Shafii did not clearly point out $\mathrm{v}, \mathrm{T}+\mathrm{Ast}$ bear the burden of being guarantors to these women. Ne rti less, it can be understood that the guarantor is the Islamic s $\mathrm{v}$ nment through the funds of bayt al-mal (the state treasury).

Apart from that, a in whom wo converted to Islam after having intercourse y th her husband is entitled to receive her dowry. If she had not obu if ed the dowry from her husband, she is entitled to ask for it if converted to Islam or 7 t. In this case, the role of legal authority holders in Islamic government is very important, because should the husband had not entered Islam, demanding the dowry from him might not be an easy task. However, if the husband had converted to Islam, then it will be easier to handle because the couple have become the subject of Islamic law.

The second thing that Shafii raised into concern was the dispensation of legal sanctions and economic consequences to women who convert out of Islam (murtaddah). Shafii stated that if the woman concerned is a free person, she is just put into prison; if she is a slave, then the law sanctions is to serve the society in 
which she lives, and the community is obliged to pay the wages to her according to the Islamic rules. This is very different to the sanction against the person who converts out of the religion should the person concerned be a man, then he should be killed on charges of apostasy unless he repents and returns to Islam.

Shafii's argument related to the case of not giving a capital punishment to Muslim women who convert out of Islam but rather 'only' putting them in jail was analogized to the Sunnah (practices of the Prophet Muhammad) that prohibits the killing of women even in the territory of war (dar al-harb). To Shafii, such legal sanction is a declaration of respect shown by Islam to women. Such respect expressed by Shafii is one of the essential hur anistic values in Islamic law.

\section{Humanistic Phylosophical Analysis or Women Existence In Law of Marriage}

The first thing to be elabc uted is khitbah (engagement). Engagement is a preliminary eve $t$ bf fore marriage which may provide an opportunity for the nrospective husband and wife to continue their relationship into itage or to cancel it.

In Islamic law, engagr $n$ en gains an important position for the purpose just mentioned order to avoid regrets in the future; as well as giving a chan for the prospective couple concerned to know each other's ch arac $r$ and attitude through nazhr, http:// translate.googleusercr a prit com/translate_f-_edn66 not only with ra'y (literally means ${ }^{\wedge}$ 'es, ${ }^{7}$ at it refers to looking at glance).

Shafii's con or considering this case does not only apply unilaterally to benefit hen, but also for the freedom of women in determining the choice of her future husband. Although a woman is bound by her guardian's role in marriage until the wedding carried out, Shafii guarantees dispensation to her to publicly declare her judgment against her prospective husband. ${ }^{49}$

49 'Ala tara 'ann al-mar'ah mustakhaffah law qalat la ankih rajul hatta arah mutajarrid aw hatta akhbarah bi al-fakhishah fa 'ardah fi al-halayn fa tajarrad laha. For more information see Al-Shafii, al-Umm, chapter 5, p.39. In the opinion of the writer the phrase "la ankih rajul hatta" is a statement of attitude for a woman to choose whether she agrees or not to accept a man who wants to propose and marry her. By this, a woman gains a complete freedom to decide what is best for her. 
Still in the same book, Shafii offers his ideas about al-mar'ah al-rashidah, (a capable woman) - which is in a modern language may be translated as a woman who has a high spiritual, emotional and intellectual astuteness - can have the right to choose her prospective husband and to marry herself (i.e. without her guardian's permission).

In terms of prohibition to perform a marriage at the time of 'iddah (period of respite for a woman after a divorce from her husband), Shafii allows a man to propose her. For this he explained that:

'Ala tara ann Allah harram an ya'qid al-nikah hatta tanqadi al-iddah wa lam yahrum al-ta'rid bi al-khitbah wa la'c yac 'kuraha wa yanwiy nikahaha bi al-khitbah laha wa al-dhikr ha al-niyah nikahaha sebab al-nikah.

Shafii wants to give opportuniti sto omen to enrich the alternatives at the time of her 'iddah, $\mathrm{b}-\mathrm{a}$ ' $\mathrm{c}$ ? at that moment they are in transition, between Ruju' (bac' to their ex-husbands) or not. Here, the presence of one man who var is to propose a woman at the time of her 'iddah gives her $m$ ntions rather than cornering her only with two options between aking Ruju' or not; so allowing this to happen gives the wom in tr er alternatives with whom she decides to move on her fami ${ }^{n}$ ? after the divorce.

The second thing is a rarding mahr (the dowry). Mahr is not a price (thaman) given by th hus, and to his wife. Women are married as "human beings" an (n t t all the same as the "goods or stuff" in the context of trar $M_{r}, r$ is an identity of a husband's respect to honor his wife a opriate to his ability and willingness of his wives. So, mahr is a "ful $y$ reserved" right that belongs to the wife.

In common view of jurisprudence, such belongings can be used by a wife as she pleases, without the intervention of others, including her guardians or even her own husband. It is indeed intended that, mahr can be used by a wife as ransom payment in her divorce accusation against her husband which is known as khul. If the divorce accusation is taken without any payment of ransom, it is called faskh.

Shafii compiled the discussion about the dowry in a topic titled "dowry and trade" (al-mahr wa al-bay'). The first impression that emerges is the comparison between the status of women in 
dowry and the status of items in a trade. However, in the middle of the discussion Shafii affirmed that a transaction of a marriage is not the same as that of a trade; including should there be a case of a divorce which results in the return of the cost of a dowry.

Regarding a dowry given by the husband to his wife, should there be a divorce before a couple having intercourse, the wife is entitled to receive $3 / 4$ part of the dowry. This is so since half of the dowry is understood as the price of the 'trade transaction' in a marriage while the other half is considered as the charity given by the husband to his wife. So, in a case of a divorce prior to having intercourse, the sum of the dowry that a wife must return to her former husband is $1 / 4$ of the whole dowry o $1 / 20$ the value of the charity part. This $3 / 4$ part received by the $J-w$, after the divorce amounts from the half $\left({ }^{2} / 4\right)$ of the transa $+1 n$ value of dowry plus $1 / 4$ from the charity part to the overall y a d the dowry. Thus, the ex-wife is obliged to return only half in amount of the charity part of the dowry while the price of me trade transaction part of the dowry is wholly owned by her.

Such is a practical illus tion of the difference between dowry and trade. Regarding the ti nsaction value of the dowry, the

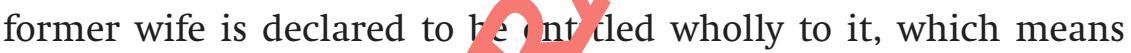
that there is no obligation to $r$ to return it despite a condition that a divorce occurs befr an intercourse taking place. Contrarily to a trade, should ther be a cancellation of a transaction all the price of goods not yet $n \in 1$ by a buyer is fully refunded.

It seems tha she 1 paralleled between cancellations of a transaction before, goods are received by a buyer with a divorce occurs in a marriage 'tr insaction' before a couple having intercourse. Nevertheless, the main subject is his assertion that a marriage is very much different to a trade, so applying a qiyas (analogy) between the two should be differentiated proportionally.

From this explanation of the dowry and trade, it can be obtained an understanding that in exchange for a dowry, a wife is not to be possessed, but merely to be taken benefit from her. This becomes the estuary of the issue of a wife's rights to be treated well as a human, not as merchandise. Thus, intercourse activities done by the husband to his wife are lawful due to the dowry given by 
him, but the dowry concerned does not make him having a single bit of right to impose whatever he wishes onto his wife. While on the other hand, the goods in a trade can be wholly owned as well as used by the buyer as he or she pleases including reselling, mortgaging or leasing them.

In a methodological study by Esposito, qiyas was employed first time on the dowry issue. In this case, qiyas operated in an analogical situation established between the loss of virginity caused by a marriage and a penalty against theft written in the Quran in the form of cutting the thief's hand. According to him, the minimum standard of dowry in Kufa and Medina was commensurate to the value of goods stolen that lead to hand $\mathrm{cu}^{1}$ ing sanction. http:// translate.googleusercontent.com/translate__e Esposito did not give a complete inform in bout who was the first person using the method of qiyas in a se swry.

The third thing is the right to 6 r $\geqslant$ adequate sustenance both physically and spiritually. In the Quran there are several verses stating that the provision of liveli oo to all family members, especially to wives, is the respons " 1 ity of the husband as the head of a family, ${ }^{50}$ which were then refe nced by Shafii in his fiqh. ${ }^{51}$

The next reference is $h+$ ro hadith the Prophet; one of which is about a man consul ing bim in a matter of using his money worth one dinar for his fa $1{ }^{1} \mathrm{~V}$ living ${ }^{52}$ and the other is relating to the case of a woman com Jain ing to the Prophet about her husband that was very stingy an $r$ tot pay enough attention to the needs of their livelihoods. ${ }^{53}$

With his mc a of istidlal, Shafii explains that a husband is obliged to provide ad quate and decent provision to his wife and children. A good measure of provision is at least commensurate to the common economic conditions, including the home situation

${ }^{50}$ A number of the verses alike are the Quran, Surah 4 (al-Nisa '), verses 3, 17, 33; Surah 2 (Al-Baqarah), verses 228, 233; Surah 65 (al-Talaq), verse 6; Surah 33 (al-Ahzab), verse 50 .

${ }^{51}$ Al-Shafii, al-Umm, chapter 5: p. 93, 95, 114.

${ }^{52}$ _ p. 94, 114. This hadith was narrated by Shafii from Sufyan from ibn 'Ajalan from Sa'id ibn' Abi Sa'id from ‘Abi Hurayrah.

53 p. 114. This hadith was narrated by Shafii from Sufyan from Hisham ibn 'Urwah from his father from ' Aishah (may Allah bless upon her). 
and property. So, if a husband is not able to comply with this obligation, then his wife should not be forced to stay with him. Even, according to Shafii, it is preferable for them to be separated. When the husband decides to divorce her, he still remains obligated to give her a provision until the expiration of the 'iddah time because during this interval period the husband still has the right to remarry her. Furthermore, in this period a husband is even obliged to provide a maid for his wife if she does not have one.

A husband's inability to provide a decent living to his wife results in her having the right of whether asking for a divorce or to remain living as a family with her husband whether the couple has had intercourse or not. Exclusion to uch matter is, when the wife agreed to marry her husband, $s^{2} s$, equipped with a full awareness of the conditions of her 1 nd or she was fully prepared with any upcoming situation

Regarding to this, Shafii expla o $e^{\text {' that: }}$

Wa in nakahathu wa hiya ta'r 'usratah fa hukmuha wa hukmuh fi'usratih ka hukm al-mar'ah tar 'ih -rajul musira fa yu'sir li'annah qad yusir ba'd al-'usr wa yu' ha'a al-yusr wa qad ta'lamuh mu'sira wa hiya tara lah hirfah tughn cuva latughnih wa tughniha aw man yatatawwa' fa yu'tih ma $a_{c}$ hn $a$.

What was describry $v$ Shafii shows the romance and harmony of compassion stween the husband and wife, more than just a transactio of roviding sustenance in enduring a family life.

Whether the wo en's attitudes are like the picture just mentioned or not $b$ an still staged his fiqh with a firm and clear explanation that rece ing provision is the right of a wife from her husband, and she has the right to self-determine over her husband's treatment in the matter of sustenance. This is so because provision is one of the basic physical needs of living to every human being. This assertion is to meet the right upon this need, including providing protection for a wife against her husband's unjustified treatments as experienced by the wife of Abu Sufyan who complained to the Prophet as told in the hadith just quoted.

Similarly, in the case of the spiritual provision (i.e. biological desire needs), women have the right to determine her choice towards her husband's treatment and ability. Regarding to this matter, Shafii 
even purposively associated closely with the physical provision. He stated that a woman can refuse or relinquish to have intercourse with her husband who has not given a dowry that becomes her legal right, while the husband still has to provide provision for her. But, if the dowry had been given to her in cash all or in part, she has no right to refuse having intercourse. When she volunteered herself to have intercourse with her husband even before receiving the dowry, then the value of such case is the same as the harmony of love just described, so much so that their marriage really becomes a union of feeling and wishes between a husband and his wife in embodying sexual relations in the form of the highest expression of love which means a total physical and emc ion 1 blend between the two. ${ }^{54}$

The fourth thing is the right to $b+1$ ed well and fairly. Shafii, taking into account both sourc oot he Quran ${ }^{55}$ and the hadith of the Prophet, explained that a $v_{2}$ ' s should be treated well in the fulfillment of her physical, m . crial and spiritual needs. ${ }^{56}$

Specifically in the matter or spi itual sustenance (i.e. the fulfillment of biological desires), nomed that a woman should only be copulated through her farj Jagina), not through any other places, by any method desired of th husband, and must be carried out of her menstrual perio s, an intercourse in her menstrual period or carried out thro s any other places than her genital, for example through her rec $\mathrm{m}$ (i . anal sex) as ever stated in the hadith of the Prophet, is state a ly prohibited in the Islamic law.

In the textu ar contextual discourses, farj is often translated as "hono" „rere it is then understood that copulating the woman only throuch her genital means upholding her honor. Contrarily, an intercourse which is done through other than her farj or during her menstrual period means insulting her honor and harming her both physically and psychologically. It is pointed out that an intercourse which is done while menstruating can cause an infection in the female genetic system and a bleeding in her uterus

${ }^{54}$ Hassan Hathout, Revolusi Seksual Perempuan : Obstetri dan Ginekologi dalam Tinjauan Islam (Female Sexual Revolution: Obstetrics and Gynecology in Islamic Review), (Bandung: Mizan, 1994), p. 83.

${ }^{55}$ The Holy Quran, Surah 4 (al-Nisa ') verse 18; Surah 2 (Al-Baqarah) verse 223.

${ }^{56}$ Al-Shafii, al-Umm, chapter 5, p. 93. 
as well as contributing an etiological role in the urinary and sperm tracts in male genital.

Furthermore, apart from having the right to be treated well, a woman also has the right to be treated fairly among the wives of a husband. Each of a husband's wives has an equal right to their needs. To fulfill such rights, Shafii suggested the husband organizing a fair distribution; including making a fair schedule in dividing the days and nights for his wives, and this method is mandatory. It is intended primarily to the kinship psychological influence. Dealing with this matter, he proposed a concept of dividing the days and nights among the wives that for a virgin wife (bikr) is allocated for seven days while for a non-virgin wife (+ ayy b) is allocated for three days.

http://translate.googleusercont 10 n/translate_f_edn90 This is due to a consideration that virgity hly happens once.

There is one critic regarding t s a ctice of marriage in the form of polygyny (which is one forr of polygamy), where a family is composed of one husband and hor than one wife, as quoted in the study carried out by $\mathrm{Tu}$ and Frese. ${ }^{57}$ The critic stated that polygyny can increase a ma. $s$ dominance by increasing the number of family members $1 i$, geria viewed and analyzed this problem differently, he int " p p thed that in a polygyny the first wife becomes the "husband" $f$ "voung wife/wives" so much so that she might be very cruel to $r /$ th $m$.

Shafii, legally $+\mathrm{r}$ agh his jurisprudence, has given a guidance to do jus a hong the wives, including setting up a good organization ang them. This is intended to avoid the abuse of an 'older wife' to y unger one/ones or vice versa, the younger wife abuses her elders, in acquiring rights.

The fifth is the right for a wife to file for a divorce. A wife is given the opportunity to file for a divorce against her husband in front of judges due to some evidences that can be justified for the ground of filing. Such filing is called al-khul, i.e. returning the dowry to the husband to obtain a divorce status. If after due

${ }^{57}$ Edith Turner and Pamela R. Frese, "Marriage" in Eliade, Mircea ed. The Encyclopedia of Religion, vol. 9. (New York: Macmillan Publishing Company, 1993), p. 220. One other form of polygamy is polyandry which is a family comprised of one wife with more than one husband. 
processes based on the evidences presented by the wife that turn out to support her filing the judge determines that the wife is freed from the obligation to return the dowry, the case is called faskh.

Shafii gives the opportunity for the wife to file a khul' against her husband, not only at the time of the husband being unhealthy, but also at other situations whether both are healthy, both are sick or one of them is healthy. Regarding to this, he states that:

“Wa al-khul'fial-marad wa al-sihhah ja' iz ka ma yajuz al-bay'fi al-marad wa al-sihhah sawa' wa'sawa' ayyuhuma kan al-marid'ahaduhuma dun al-'akhar aw huma ma'a wa yalzimuh ma samiy al-zawj min al- talaq. ${ }^{n 58}$

The emphasis presented in the statem nt ist mentioned is that khul' has the same level with a trade tr $\mathrm{sa}^{-}$ons, even khul' is part of the trade transactions. On this bas fir argued that the permissibility prerequisite of khulu' is i veq valent status to the trade. According to Shafii, a wife filin a 'h the value of the dowry to her husbar 4 , as a similar thing applies to a cancellation of a trade transaction. ${ }^{59}$

There are three key words the discussion about a divorce filed by a wife against her husbai (n the conception of Shafii's jurisprudence, namely: (1) m n 17 a wife's willingness, and (3) a trade transaction. All of the th "re things work interactively.

A dowry given by a sband to his wife is not the same as a price in a trade. When th hus and divorces his wife, the ex-wife is obliged to return only of the dowry. However, if the wife is the person filing for a di a ce (hulu'), then she is obliged to return all the value of the dow ' as in this case, khulu' is considered equal to a trade transaction.

With this third keyword which is the trade transaction, a wife filing a khulu' is regarded to view that her marriage (through the dowry) is nothing more than a trade transactional activity, so she is subjected to a law sanction to return all the values of the dowry as a similar thing applies to a cancellation of a trade transaction. Nonetheless, Shafii still insists that khulu' is a legitimate right of

${ }^{58}$ Shafi'i, al-Umm, chapter 5, p. 214, 215.

${ }^{59}$ The characteristics of khul 'differs from talaq (a divorce sponsored by a husband). Shafii stated that the amount of dowry that a divorced wife to her husband is part of the dowry. Shafii, al-Umm, chapter 5, p. 215. 
a wife. Whatever the difference in attitude of the wife/wives in accepting or rejecting the conditions that do not meet her/their rights, she/they still obtain legal protection in Islamic law.

From this discussion, it can be assessed Shafii's consistency in fighting for women humanization covering their dignity, protection for them, freedom, and their rights as individuals.

\section{CONCLUSION}

From the exploration of the literature on the monumental works of Shafii, it can be concluded the following;

First, Shafii concerns very much on the women existence in the law of properties, including: (1) Equal $r$ ght and the freedom of trade ('ahliyah al-tasarruf) between wo en men, both in terms, khiyar, or trade contracts. (2) Th is ness and economic opportunities for women in the contex ${ }^{t} \mathrm{th}$ absence of obligation in performing Friday prayers for the $n$ ' Islam provides more time and op ortunty for them to conduct economic transactions. (3) Womei ha e every right to manage, organize and spend their owned monerty.

Secondly, the humanistic values of women in the state law on economic issues rela ec to religious conversion and social relations in political setti os elaborated below: (1) economic security for non-Muslim v o. en (dhimmiyah) who convert to Islam, besides Christians, Jews and hl book Islam, in a state of pregnancy, they are given the $r^{-1}>$ get a living stipend from the state until childbirth; if cey are breastfeeding, they are entitled to breastfeeding wag ( 2 ) Christians women who convert to Islam after having intercour e with their husbands is entitled to obtain a dowry. If she has not obtained the dowry, she is entitled to demand for it to her husband, either he has converted to Islam or not and either she request it directly or through the Islamic government advocacy. (3) The dispensation on legal sanctions and economic consequences to women who convert out of Islam / murtaddah. Shafii stated that if the woman concerned is a free person, she is just put into prison; if she is a slave, then the law sanctions is to serve the society in which she lives, and the community is obliged to pay the wages to her according to the Islamic rules. This is very different to the sanction against the person who converts out of the religion 
should the person concerned be a man, then he should be killed on charges of apostasy unless he repents and returns to Islam

Thirdly, the value of women in the marriage laws of humanity, including (1) In the process of khitbah or engagement, Shafii guarantees dispensation to women to declare their assessment openly (whether they refuse or receive it) against her prospective husband. In fact, Shafi furthermore brings up an idea that a good and knowledgeable woman (al-mar'ah al-rashidah), has every right to determine her future husband and marry him. About Mahr or dowry is the identity of husband rewards to honor his wife, therefore mahr is a wife's fully reserved right. (2) The right to earn an adequate sustenance both physically and spiritually fro a the husband as the head of the family. And the right to be treat $w$ and fairly in the fulfillment of physical, material and spiri 13 eeds. And a wife is given the opportunity to file for a divors in ont of the judges or khulu' by presenting some justified evic 'n.

\section{Daftar $\hat{P}$,taka}

Anonymous, "Presidents; P 'it 1 Behavior" in the Getting There, Economist Journa? v 1. 340, 21 September 1996 , "Presidenti AElections, Political Parties; Islam; Voter Behaviors; Socian in hge" in Islam and Ballot Box, Economist Journal, Vol. 4 . I ay 31, 1997

Chalil, Moenawar, Bios $f$ Empat Serangkai Imam Mazhab (A Biography of Four Imams of the School of Thought), Jakarta : Bulan Bintang, 1955

Dessouki, "Islamic Modernism," in Mircea Eliade, ed., The Encyclopedia of Religion, $\mathrm{tt}$

Djamil, Fathurrahman, Filsafat Hukum Islam (Philosophy of Islamic Law), Jakarta: Logos, 1997

Hathout, Hassan, Revolusi Seksual Perempuan : Obstetri dan Ginekologi dalam Tinjauan Islam (Female Sexual Revolution: Obstetrics and Gynecology in Islamic Review), Bandung : Mizan, 1994 
Hasyim, Syafiq, ed., Menakar "Harga" Perempuan : Eksplorasi Lanjut atas Hak-hak Perempuan dalam Islam (Measuring the "Price" of Woman: Advanced Exploration on the Rights of Women in Islam), Bandung: Mizan, 1996

Jundi, Al-, al-Imam al-Shafii Nasir al-Sunnah wa Wadi 'al-Uhsul, CairoEgypt: Dar al-Kaib al-’ Arabi, 1966

Khadduri, Majid, "Al-Shafii" in Mircea Eliade, ed., The Encyclopedia of Religion, vol. 13, New York: Macmillan Publishing Company, 1993

Khallaf, 'Abd al-Wahhab, Ilm Ushul al-Fiqh, Kuwait: Dar alQalam, 1977

Masud, Muhammad Khalid, Islamic Philoopp" of Law and Social Change, translated into Indonesi in tydian W. Asmin, titled Filsafat Hukum Islam dan su han Sosial, Surabaya: Al-Ikhlas, 1995

Mayer, Ann Elizabeth, "Islamic Law snari ah", in Mirca Eliade, ed., The Encyclopedia of Religion, vo 7, New York: Macmilan Publishing Company, 19

Melloan, George, "Foreign Policy, Human Rights; Religion” Who's in Charge of Human ig - hese Days?, Wall Street Journal, May 12, 1998

Shafi, Al-Imam al-, al-U arm Beirut-Lebanon: Dar al-Kutub al'Ilmiyah, 1992

Suyuti, Jalal al-Din A 4 al-Rahman ibn Abi Bakr al-, Uqud alZabarjad 'al I lad al-Imam Ahmad, Beirut: Dar al-Kutub al-Ilmiyah, 1s?

Watt, W. Montgomery, Islamic Philosophy and Theology: An Estended Survey, Edinburgh: Edinburgh University Press, 1985

Zuhaili, Wahbah, The Quran: Paradigm of Law and Civilization, translated into Indonesian by M. Luqman Hakiem and M. Fuad Hariri, titled : Al-Qur'an : Paradigma Hukum dan Peradaban, Surabaya: Risalah Gusti, 1996 